\title{
The Impact of Rainfall and Temperature on Peak and Off- Peak Urban Traffic
}

DOI:

10.1007/978-3-319-98812-2_36

\section{Document Version}

Accepted author manuscript

Link to publication record in Manchester Research Explorer

\section{Citation for published version (APA):}

Essien, A., Petrounias, I., Sampaio, P., \& Sampaio, S. (2018). The Impact of Rainfall and Temperature on Peak and Off-Peak Urban Traffic. In Database and Expert Systems Applications : 28th International Conference, DEXA 2018, Regensburg, Germany. (pp. 399-407). (Lecture Notes in Computer Science). Springer Nature. https://doi.org/10.1007/978-3-319-98812-2_36

Published in:

Database and Expert Systems Applications

\section{Citing this paper}

Please note that where the full-text provided on Manchester Research Explorer is the Author Accepted Manuscript or Proof version this may differ from the final Published version. If citing, it is advised that you check and use the publisher's definitive version.

\section{General rights}

Copyright and moral rights for the publications made accessible in the Research Explorer are retained by the authors and/or other copyright owners and it is a condition of accessing publications that users recognise and abide by the legal requirements associated with these rights.

\section{Takedown policy}

If you believe that this document breaches copyright please refer to the University of Manchester's Takedown Procedures [http://man.ac.uk/04Y6Bo] or contact uml.scholarlycommunications@manchester.ac.uk providing relevant details, so we can investigate your claim.

\section{OPEN ACCESS}




\title{
The Impact of Rainfall and Temperature on Peak and Off-Peak Urban Traffic
}

\author{
Aniekan Essien $^{1 \bowtie}$, Ilias Petrounias ${ }^{1}$, Pedro Sampaio ${ }^{1}$, and Sandra Sampaio ${ }^{2}$ \\ ${ }^{1}$ Alliance Manchester Business School, University of Manchester, Oxford Road, M13 9PL \\ ${ }^{2}$ School of Computer Science, University of Manchester, Oxford Road, M13 9PL \\ aniekan.essien@manchester.ac.uk \\ ilias.petrounias@manchester.ac.uk \\ pedro.sampaio@manchester.ac.uk \\ sandra.sampaio@manchester.ac.uk
}

\begin{abstract}
This paper focuses on quantifying the effect of rainfall and temperature intensities on urban traffic characteristics in peak and off-peak respectively hours using traffic data from Greater Manchester, UK, as a case study. Three broader issues are addressed: (1) the impact of rainfall on urban traffic; (2) the impact of rainfall intensity on traffic flow parameters at both peak and off-peak periods; (3) the impact of atmospheric temperature level on peak and off-peak urban traffic. Our contribution arises both from the combination of data sources included in the study as well as the separate analyses of peak and off-peak weather effects on traffic. This is the first study undertaken in a real urban environment with reduced operating speed (30 $\mathrm{mph}$ ). This research can provide urban traffic policymakers with crucial information that can be used to modify or develop traffic planning decisions in order to maximize the traffic network utilization.
\end{abstract}

Keywords: Traffic Analytics, Traffic Flow Analysis, Data Science.

\section{$1 \quad$ Introduction}

Over the years, it has been identified that harsh weather can considerably affect traffic flow parameters by influencing driving behaviour, travel demand, travel mode, safety, as well as traffic flow characteristics [1-5]. In terms of traffic operation, rain conditions reduce traffic capacity and operating speeds, thereby increasing congestion and road network productivity loss. The incorporation of weather-related data for traffic management enables a clear understanding of the dynamics of traffic flow modeling, especially in geographical locations with the tendency of severe weather conditions. Despite the vastness of studies investigating whether weather affects traffic, there is still a dire need to quantify the impact of weather conditions on traffic operation within urban road networks. The limitations in understanding the direct impact on traffic by weather conditions minimizes the potential for transportation policymakers to capitalize on additional intelligence provided by weather-related data sources in order to develop improved traffic management strategies. This leaves the presence of a number of gaps or opportunities for new and exciting research within this area. 
One of the main limitations addressed by this study is the fact that only few studies have investigated the impact of weather conditions on urban traffic. This is possibly because urban links are shorter in length, usually have lower speed limits, and have more interrupted traffic [6]. Secondly, peak and off-peak periods should be analyzed separately during weather-traffic analyses. Policymakers can benefit from a deeper understanding of the effects of weather conditions on peak and off-peak periods leading to better planning decisions or traffic control modifications that will be applied to effectively control traffic congestion. This research differs from existing studies by focusing on weather impact on urban traffic rather than freeway/motorway/highway traffic. The remainder of this paper is organised as follows. Section 2 presents related studies, while the Methodology and Data are presented in Section 3. The results are presented and discussed in Section 4. The final section presents the conclusion and future research opportunities.

\section{$2 \quad$ Related Work}

Many studies have attempted to investigate the relationship between weather and traffic. For instance, Jones and Goolsby [7] reported a 14\% reduction in operating speed during rainfall. Smith, Byrne [8] observed that light rain decreased capacity by $4 \%$ to $10 \%$, while heavy rain caused a reduction in the range of $25 \%$ to $30 \%$. Ibrahim and Hall [9] performed a regression analysis on weather data and found out that light rain caused a reduction of about $1.1 \mathrm{mph}$ in operating speeds during free-flowing conditions and 4 to $8 m p h$ in congested conditions. In heavy rain, they observed a reduction of $8 m p h$ to $10 m p h$ during capacity conditions. Mahmassani, Dong [10] showed that adverse weather can affect traffic by increasing demand, as well as shifting the peakhour demand. Similarly, Wang, Yamamoto [11] observed a reduction in operating speeds to about $6 \%$ to $8 \%$ during heavy rainfall and that the magnitude of the weather impact was dependent on road network characteristics, such as number of lanes, and the size of road. Other studies claim that changes in rainfall intensity is what affects the traffic speed negatively $[2,6,8,12]$.

A step in the right direction would be the analysis and quantification of the impact of weather on traffic data within an urban setting (reduced operating speed - 30 $\mathrm{mph}$ ), as opposed to the vast majority of studies that consider freeway traffic [3, 9, 13-16]. Moreover, identifying how traffic is impacted at peak and off-peak times can provide additional information to policymakers for developing improved traffic management policies. 


\section{$3 \quad$ Methodology and Data}

The traffic data used within this study was provided by Transport for Greater Manchester (TfGM) and comprised observations of average speed, flow, density, and travel time. The data was collected using a combination of Inductive Loop Devices (ILD) and Bluetooth sensors on an urban road (Chester Road - A56) in Stretford, Greater Manchester, UK, as depicted in Fig. 1. This represents an ideal characteristic of serving as a conduit from a residential area to the city centre. Landmark locations around are the Old Trafford Stadium (Manchester United) in addition to other leisure points like shopping malls, clubs, restaurants, etc. The study period spans from 1 January 2014 to 31 December 2014. The study area has a speed limit of 30mph.

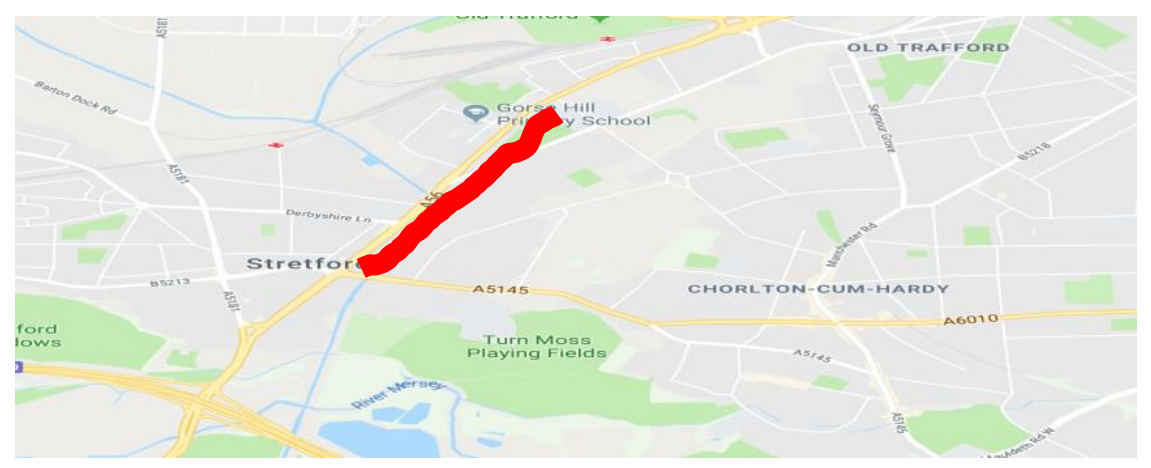

Fig. 1. Map of Study Area (source: Google Maps)

The weather data obtained during the study period comprised hourly observations of temperature $\left({ }^{\circ} \mathrm{C}\right)$ and precipitation $(\mathrm{mm})$. The rainfall was categorized as Light $(<$

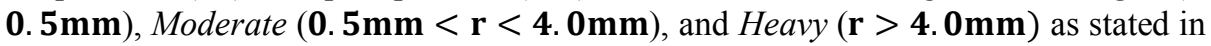
the SYNOP FM-12 weather equipment. Weather data was obtained from the Centre for Atmospheric Studies (CAS), University of Manchester. The weather stations are located within a 3-mile radius of the study area. Holidays and weekends were excluded from the analysis, as these would present significantly differing traffic patterns to the daily peak and off-peak patterns used within this study. The workdays were further subcategorized into peak and off-peak hours. The peak hours were identified by performing analysis and descriptive statistics on the data, which revealed the peak hours (excluding outliers) to be $08: 00$ to $10: 00,17: 00$ to $19: 00$.

\section{$4 \quad$ Results}

The first step in the process of this analysis was the visualization of the provided traffic dataset by producing speed-density-volume (V-K-Q) plots for peak and off-peak hours, which are presented in Fig. 2. This was compared to existing traffic stream models in the literature [17] and agreed with the Greenshields traffic stream model. Table 1 presents the descriptive statistical analysis for the traffic dataset. All the tables 
also present the Standard Deviation (SD), Standard Error (SE), Degree of Freedom ( $d f$ ) and Mean Square (MS) for the respective groups. As shown in Table 1, all p-values are statistically significant at the 0.05 level, implying that the null hypothesis cannot be rejected. Also, the average speed at off-peak periods is higher than that of the peak periods, which makes sense and shows the level of traffic congestion during peak hours.

Summarily, there is a $35 \%$ reduction in average speed during peak periods, an increase of $157.5 \%$ and $154 \%$ for volume and density respectively. This represents a significant increase in traffic congestion during peak periods.
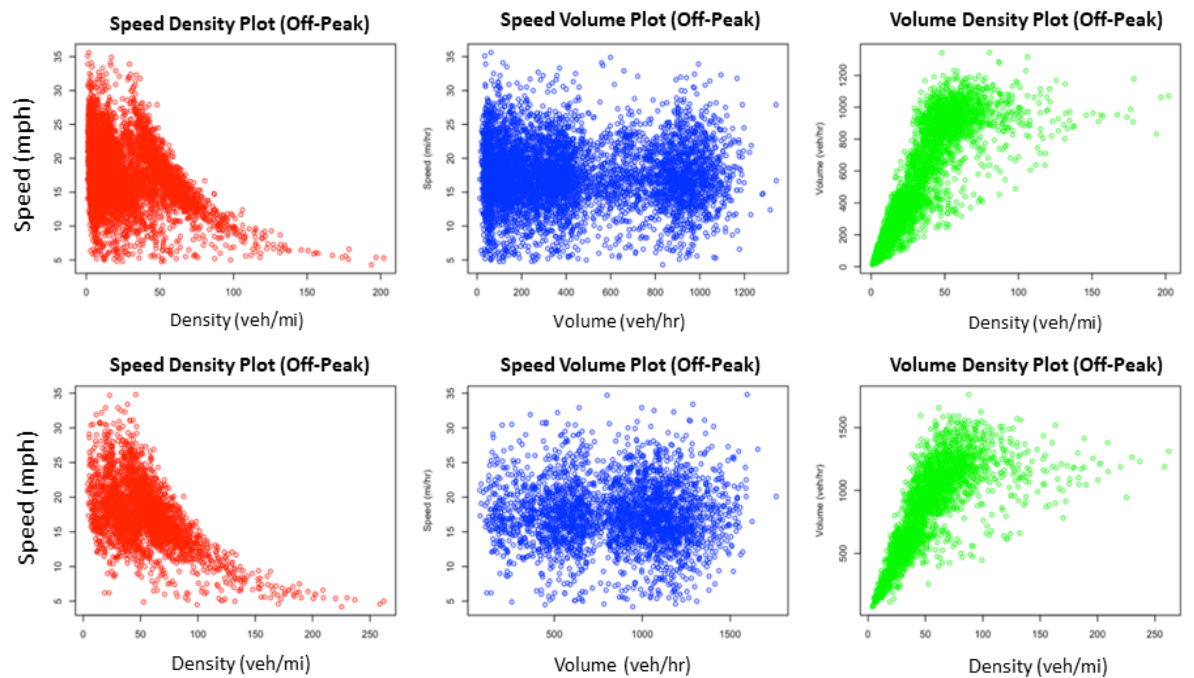

Fig. 2. V-K-Q Relationships for Peak and Off-Peak period

\subsection{Precipitation}

Table 2 displays the descriptive statistics and single factor ANOVA for the groups of rainfall intensities during peak periods. As can be seen from the table, there is a significant difference $(p<0.05)$ between all the rainfall intensities and the traffic flow characteristics (i.e. speed, volume, and density). What stands out in the table is that heavy rainfall negatively impacted average operating speeds by $9.74 \%$, equivalent to a $2-3 m p h$ average speed reduction. More specifically, average speeds were reduced by $2.61 \%$ and $9.74 \%$ during moderate and heavy rainfall respectively.

\subsection{Temperature}

The temperature observations were classified as Freezing (below $5^{\circ} \mathrm{C}$ ), Cold (between $5^{\circ} \mathrm{C}$ and $10^{\circ} \mathrm{C}$ ), Normal (from 10 to $15^{\circ} \mathrm{C}$ ), Warm (between $15^{\circ} \mathrm{C}$ and $20^{\circ} \mathrm{C}$ ), and Hot (above $20^{\circ} \mathrm{C}$ ). Tables 3 and 4 present the descriptive statistics for the respective groups, at off-peak and peak periods respectively. In Table 4, there is a clear trend of increase in volume with temperature at peak periods. However, average speed is reduced by $36.5 \%$ at hot temperatures, which translates to a speed reduction of 5-6mph. 
Table 1. Speed-Volume-Density descriptive statistics at Peak and off-peak periods

\begin{tabular}{|c|c|c|c|c|c|c|c|c|c|c|c|}
\hline \multicolumn{6}{|c|}{ DESCRIPTIVES } & \multicolumn{6}{|c|}{ ANOVA } \\
\hline Section & $\mathrm{N}$ & Mean & SD & $\mathrm{SE}$ & Max & $\begin{array}{l}\text { Compari } \\
\text { son }\end{array}$ & $d f^{\prime}$ & MS & & $p$-value & F crit \\
\hline $\begin{array}{l}\text { Speed } \\
\text { (Off }\end{array}$ & 4301 & 26.8 & 4.18 & 0.06 & 35.6 & $\begin{array}{l}\text { Between } \\
\text { Groups }\end{array}$ & 1 & $\begin{array}{l}110143 . \\
26\end{array}$ & 5961.16 & 0 & 3.84 \\
\hline $\begin{array}{l}\text { Peak) } \\
\text { Speed }\end{array}$ & & & & & & & & & & & \\
\hline $\begin{array}{l}\text { Speed } \\
\text { (Peak) }\end{array}$ & 1771 & 17.4 & 4.57 & 0.11 & 34.8 & $\begin{array}{l}\text { Within } \\
\text { Groups }\end{array}$ & 6070 & 18.48 & & & \\
\hline Total & 6072 & 17.5 & 4.59 & 0.26 & 35.6 & Total & 6071 & & & & \\
\hline $\begin{array}{l}\text { Volume } \\
\text { (Off }\end{array}$ & 4301 & 431 & 349 & 5.32 & 1209 & $\begin{array}{l}\text { Between } \\
\text { Groups }\end{array}$ & 1 & $\begin{array}{l}5781615 \\
28\end{array}$ & 6063.47 & 0 & 3.84 \\
\hline $\begin{array}{l}\text { Peak) } \\
\text { Volume } \\
\text { (Peak) }\end{array}$ & 1771 & 1110 & 177 & 4.22 & 1762 & $\begin{array}{l}\text { Within } \\
\text { Groups }\end{array}$ & 6070 & $\begin{array}{l}95351.6 \\
\underset{1}{9}\end{array}$ & & & \\
\hline Total & 6072 & 628 & 396 & 4.23 & 1762 & Total & 6071 & & & & \\
\hline $\begin{array}{l}\text { Density } \\
\text { (Off }\end{array}$ & 4301 & 26.8 & 24.6 & 0.38 & 193.7 & $\begin{array}{l}\text { Between } \\
\text { Groups }\end{array}$ & & 2294876 & 3554.32 & 0 & 3.84 \\
\hline $\begin{array}{l}\text { Peak) } \\
\text { Density }\end{array}$ & 1771 & 69.6 & 24.6 & 0.65 & 262 & & 6070 & 645.66 & & & \\
\hline $\begin{array}{l}\text { (Peak) } \\
\text { Total }\end{array}$ & 6072 & 35.4 & 29.2 & 0.31 & 262 & $\begin{array}{l}\text { Groups } \\
\text { Total }\end{array}$ & 6071 & & & & \\
\hline
\end{tabular}

Table 2. V-K-Q descriptive statistics by rainfall intensity for peak periods

\begin{tabular}{|c|c|c|c|c|c|c|c|c|c|c|c|c|}
\hline \multicolumn{7}{|c|}{ DESCRIPTIVES } & \multirow{2}{*}{\multicolumn{6}{|c|}{ ANOVA }} \\
\hline Section & Intensity & $\mathrm{N}$ & Mean & SD & SE & Max & Comparison & $d f$ & $\mathrm{MS}$ & & $p$-value & \\
\hline \multirow{4}{*}{$\begin{array}{l}\text { Speed } \\
\text { (mph) }\end{array}$} & None & 1276 & 17.25 & 4.61 & 0.13 & 34.8 & Between Groups & 3 & 71.362 & 3.36 & 0.02 & 2.6 \\
\hline & Light & 399 & 17.98 & 4.45 & 0.21 & 34.7 & Within Groups & 1514 & 21.254 & & & \\
\hline & Moderate & 89 & 16.8 & 4.24 & 0.8 & 25.2 & & & & & & \\
\hline & Heavy & 7 & 15.57 & 2.55 & 0.96 & 17.8 & & & & & & \\
\hline Total & & 1771 & 17.06 & 4.6 & 0.26 & 34.8 & Total & 1770 & & & & \\
\hline \multirow{4}{*}{$\begin{array}{l}\text { Volume } \\
\text { (veh/hr) }\end{array}$} & None & 1276 & 1117 & 179.5 & 5.02 & 1762 & Between Groups & 3 & 84426.30 & 2.69 & 0.05 & 2.6 \\
\hline & Light & 399 & 1089 & 173.9 & 8.70 & 1558 & Within Groups & 1767 & 31388.54 & & & \\
\hline & Moderate & 89 & 1102 & 156.7 & 16.55 & 1453 & & & & & & \\
\hline & Heavy & 7 & 1059 & 193.9 & 73.29 & 1283 & & & & & & \\
\hline Total & & 1771 & 1005 & 264.3 & 6.78 & 1762 & Total & 1770 & & & & \\
\hline \multirow{4}{*}{$\begin{array}{l}\text { Density } \\
\text { (veh/mi) }\end{array}$} & None & 1276 & 70.62 & 27.5 & 0.77 & 262 & Between Groups & 3 & 2027.3 & 2.74 & 0.04 & 2.6 \\
\hline & Light & 399 & 67.22 & 28.04 & 1.4 & 220 & Within Groups & 1767 & 741.12 & & & \\
\hline & Moderate & 89 & 65.54 & 19.03 & 2.02 & 146 & & & & & & \\
\hline & Heavy & 7 & 57.41 & 9.62 & 364 & 72.9 & & & & & & \\
\hline Total & & 1771 & 63.08 & 28.76 & 0.74 & 262 & Total & 1770 & & & & \\
\hline
\end{tabular}

Table 3. V-K-Q descriptive statistics by rainfall intensity for off-peak periods

\begin{tabular}{|c|c|c|c|c|c|c|c|c|c|c|c|c|}
\hline \multicolumn{7}{|c|}{ DESCRIPTIVES } & \multicolumn{6}{|c|}{ ANOVA } \\
\hline Section & Intensity & $\mathbf{N}$ & Mean & SD & $\mathrm{SE}$ & Max & $\begin{array}{l}\text { Compar- } \\
\text { ison }\end{array}$ & $d f$ & MS & F & $p$-value & F crit. \\
\hline \multirow[t]{4}{*}{$\begin{array}{l}\text { Speed } \\
\text { (mph) }\end{array}$} & None & 3176 & 27.12 & 4.03 & 0.07 & 35.6 & $\begin{array}{l}\text { Between } \\
\text { Groups }\end{array}$ & 3 & 532.86 & 31.11 & $7 \mathrm{E}-20^{\circ}$ & 2.6 \\
\hline & Light & 901 & 25.79 & 4.53 & 0.15 & 35.1 & $\begin{array}{l}\text { Within } \\
\text { Groups }\end{array}$ & 4295 & 17.13 & & & \\
\hline & $\begin{array}{l}\text { Moder- } \\
\text { ate }\end{array}$ & 217 & 25.64 & 4.33 & 0.29 & 31.3 & & & & & & \\
\hline & Heavy & $\begin{array}{l}5 \\
4299\end{array}$ & $\begin{array}{l}30.22 \\
27.14\end{array}$ & $\begin{array}{l}2.41 \\
3.85\end{array}$ & $\begin{array}{l}1.08 \\
0.05\end{array}$ & $\begin{array}{l}30.7 \\
35.6\end{array}$ & Total & 4298 & & & & \\
\hline \multirow[t]{4}{*}{$\begin{array}{l}\text { Volume } \\
\text { (veh/hr) }\end{array}$} & None & 3176 & 434 & 350.4 & 6.22 & 1204 & $\begin{array}{l}\text { Between } \\
\text { Groups }\end{array}$ & 3 & 81358.3 & 0.67 & 0.571 & 2.6 \\
\hline & Light & 901 & 427 & 351.6 & 11.71 & 1209 & $\begin{array}{l}\text { Within } \\
\text { Groups }\end{array}$ & 4295 & 121659 & & & \\
\hline & $\begin{array}{l}\text { Moder- } \\
\text { ate }\end{array}$ & 217 & 406 & 310.9 & 21.11 & 1057 & & & & & & \\
\hline & Heavy & $\begin{array}{l}5 \\
4299\end{array}$ & $\begin{array}{l}313 \\
403\end{array}$ & $\begin{array}{l}334.5 \\
409.7\end{array}$ & $\begin{array}{l}149.5 \\
6.07\end{array}$ & $\begin{array}{l}707 \\
1209\end{array}$ & Total & 4298 & & & & \\
\hline \multirow[t]{4}{*}{$\begin{array}{l}\text { Density } \\
\text { (veh/mi) }\end{array}$} & None & 3176 & 27.48 & 25.31 & 0.45 & 194 & $\begin{array}{l}\text { Between } \\
\text { Groups }\end{array}$ & 3 & 1987.61 & 3.288 & $0.02^{\circ}$ & 2.6 \\
\hline & Light & 901 & 25 & 22.64 & 0.75 & 117 & $\begin{array}{l}\text { Within } \\
\text { Groups }\end{array}$ & 4295 & 604.425 & & & \\
\hline & $\begin{array}{l}\text { Moder- } \\
\text { ate }\end{array}$ & 217 & 24.21 & 21.51 & 1.46 & 146 & & & & & & \\
\hline & Heavy & 5 & 21.48 & 18.39 & 8.22 & 42 & & & & & & \\
\hline Total & & 4299 & 24.5 & 28.93 & 0.43 & 194 & Total & 4298 & & & & \\
\hline
\end{tabular}

Higher temperatures also resulted in $6.6 \%$ more traffic volume. Additionally, at peak hours, higher temperatures produced a corresponding increase in density and volumes, and a significant reduction in traffic speed. Table 3 shows that higher temperatures 
consistently drove down the traffic volume and density, while hot temperatures exceeding $20^{\circ} \mathrm{C}$ resulting in a $36.8 \%$ reduction in volume. Conversely, higher temperatures resulted in greater average speeds to the tune of $15.7 \%$ at hot temperatures. As shown in Table 5, all traffic flow parameters are statistically significant at the 0.05 level, implying that there is a relationship between temperature and traffic flow parameters.

Table 4. V-K-Q descriptive statistics by temperature intensity for off-peak periods

\begin{tabular}{|c|c|c|c|c|c|c|c|c|c|c|c|c|}
\hline \multicolumn{7}{|c|}{ DESCRIPTIVES } & \multicolumn{6}{|c|}{ ANOVA } \\
\hline Section & Intensity & $\mathbf{N}$ & Mean & SD & SE & Max & $\begin{array}{l}\text { Compar- } \\
\text { ison }\end{array}$ & $d f$ & MS & F & $p$-value & F crit \\
\hline \multirow[t]{5}{*}{$\begin{array}{l}\begin{array}{l}\text { Speed } \\
(\mathrm{mph})\end{array} \\
\end{array}$} & Freezing & 416 & 24.09 & 4.09 & 0.20 & 33.5 & $\begin{array}{l}\text { Between } \\
\text { Groups }\end{array}$ & 4 & 2664.81 & \begin{tabular}{ll|}
177.6 \\
\end{tabular} & $6 \mathrm{E}-141^{\circ}$ & 2.4 \\
\hline & Cold & 1366 & 25.32 & 4.33 & 0.12 & 35.6 & $\begin{array}{l}\text { Within } \\
\text { Groups }\end{array}$ & 4300 & 15.008 & & & \\
\hline & Normal & 1411 & 27.46 & 3.96 & 0.11 & 31.3 & & & & & & \\
\hline & Warm & 905 & 28.72 & 3.00 & 0.10 & 30.2 & & & & & & \\
\hline & Hot & 207 & 28.59 & 2.92 & 0.20 & 28.9 & & & & & & \\
\hline Total & & 4305 & 26.77 & 4.6 & 0.26 & 35.6 & Total & 4304 & & & & \\
\hline \multirow[t]{5}{*}{$\begin{array}{l}\text { Volume } \\
\text { (veh//hr) }\end{array}$} & Freezing & 416 & 1117 & 179.5 & 5.02 & 1762 & $\begin{array}{l}\text { Between } \\
\text { Groups }\end{array}$ & 4 & 84426.3 & 2.69 & $0.045^{\circ}$ & 2.4 \\
\hline & Cold & 1366 & 1089 & 173.9 & 8.70 & 1558 & $\begin{array}{l}\text { Within } \\
\text { Groups }\end{array}$ & 4300 & 3138.5 & & & \\
\hline & Normal & 1411 & 1102 & 156.2 & 16.55 & 1453 & & & & & & \\
\hline & Warm & 905 & 1059 & 193.9 & 73.29 & 1283 & & & & & & \\
\hline & Hot & 207 & 706 & 297.5 & 20.68 & 1115 & & & & & & \\
\hline Total & & 4305 & 1005 & 264.3 & 6.78 & 1762 & Total & 4304 & & & & \\
\hline \multirow[t]{5}{*}{$\begin{array}{l}\text { Density } \\
\text { (veh/mi) }\end{array}$} & Freezing & 416 & 70.62 & 27.5 & 0.77 & 262 & $\begin{array}{l}\text { Between } \\
\text { Groups }\end{array}$ & 3 & 2027.3 & 2.74 & $0.042^{\circ}$ & 2.4 \\
\hline & Cold & 1366 & 67.22 & 28.04 & 1.4 & 220 & $\begin{array}{l}\text { Within } \\
\text { Groups }\end{array}$ & 4300 & 741.12 & & & \\
\hline & Normal & 1411 & 65.54 & 19.03 & 2.02 & 146 & & & & & & \\
\hline & Warm & 905 & 57.41 & 9.62 & 364 & 72.9 & & & & & & \\
\hline & Hot & 207 & 48 & 23.64 & 1.64 & 119 & & & & & & \\
\hline Total & & 4305 & 63.08 & 28.76 & 0.74 & 262 & Total & 4304 & & & & \\
\hline
\end{tabular}

\subsection{Comparison and discussion with respect to other studies}

Over the past decades, many studies have investigated speed-flow-density relationships under rainy conditions and such studies also revealed that rainfall intensities have differing impacts on traffic flow parameters $[8,13,17,18]$. Table 6 presents a comparison of the findings from these studies. A total of ten studies were compared in terms of the results obtained. A quick look at Table 6 shows a vast variation in the reduction of speeds across the studies, which is attributable to the differences in the weather, traffic speeds, driving behavior, etc. Most studies report that light rain has the smallest impact on traffic, which supports the notion that intensity matters when considering the impact of rainfall on traffic. In addition, studies reported that temperature had a near negligible impact on traffic speed $[6,13]$, although the reverse was the case in this study. This is arguably attributed to the fact that the studies compared in Table 6 were all freeways/motorways, and thereby would be affected differently by temperature levels. However, as Tables 4 and 5 show, there are significant relationships between temperature levels and traffic flow parameters and these effects vary at peak and off-peak periods. As previously stated, this is the first study that considers urban city traffic (i.e. speeds at $30 \mathrm{mph}$ ), as opposed to other studies analyzing freeway, highway or urban freeway traffic. For instance, although [6] claim the study to be carried out in urban traffic, in reality it has been conducted on an urban motorway. Furthermore, this study also categorized the traffic into peak and off-peak periods, enabling a proper understanding and appreciation of the traffic state. 
Table 5. V-K-Q descriptive statistics by temperature intensity for peak periods

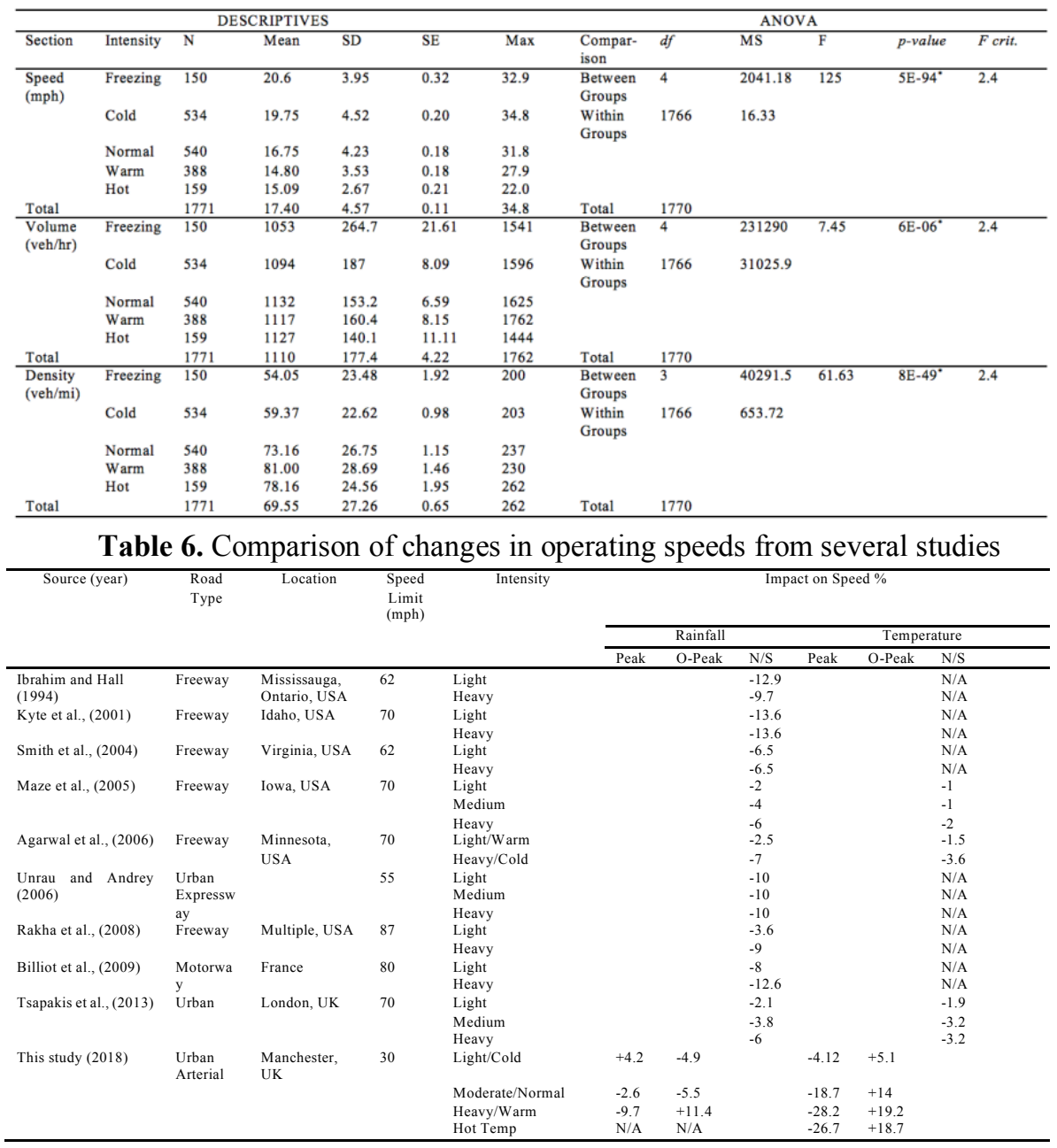

\section{Conclusion}

This study has quantified the effect of weather conditions on traffic flow characteristics. It contributes to understanding of how differing rainfall and temperature intensities affect urban traffic. The key insights derived from this study is that rainfall affects urban traffic, but is dependent on the intensity, and peak/off-peak hours. Light rainfall had no impact on peak traffic (Table 2). However, average speed reduces with Moderate and Heavy rainfall by $2.6 \%$ and $9.7 \%$ respectively. The results are however different for off-peak periods, as can be seen from Table 3 . Tables 4 and 5 present the off-peak/peak descriptive statistics respectively. This research provides policymakers with additional information towards developing effective traffic management solutions 
to improve congestion. Further research work will investigate the effect of weatherrelated data on weekends and holidays, and use of a larger dataset spanning 4 or more years that guarantee an even distribution of rainfall and temperature values enabling increases in results accuracy.

\section{References}

1. Cools, M., et al., Changes in travel behavior in response to weather conditions: do type of weather and trip purpose matter? Transportation Research Record: Journal of the Transportation Research Board, 2010(2157): p. 22-28.

2. Maze, T., M. Agarwai, and G. Burchett, Whether weather matters to traffic demand, traffic safety, and traffic operations and flow. Transportation research record: Journal of the transportation research board, 2006(1948): p. 170-176.

3. Goodwin, L.C., Weather impacts on arterial traffic flow. Mitretek systems inc, 2002.

4. $\quad$ Rämä, P., Effects of weather-controlled variable speed limits and warning signs on driver behavior. Journal of the Transportation Research Board, 1999(1689): p. 53-59.

5. Hogema, J., Effects of rain on daily traffic volume and on driving behaviour. 1996.

6. Tsapakis, I., T. Cheng, and A. Bolbol, Impact of weather conditions on macroscopic urban travel times. Journal of Transport Geography, 2013. 28: p. 204-211.

7. Jones, E.R. and M.E. Goolsby, The environmental influence of rain on freeway capacity. Highway Research Record, 1970(321).

8. Smith, B.L., et al. An investigation into the impact of rainfall on freeway traffic flow. in 83rd annual meeting of the Transportation Research Board,. 2004.

9. Ibrahim, A.T. and F.L. Hall, Effect of adverse weather conditions on speed-flowoccupancy relationships. 1994.

10. Mahmassani, H.S., et al., Incorporating weather impacts in traffic estimation and prediction systems. US Department of Transport, Washington, 2009. 108.

11. Wang, L., et al., An analysis of effects of rainfall on travel speed at signalized surface road network based on probe vehicle data. ICTTS, Xian, China, 2006: p. 2-4.

12. Theofilatos, A. and G. Yannis, A review of the effect of traffic and weather characteristics on road safety. Accident Analysis \& Prevention, 2014. 72: p. 244-256.

13. Agarwal, M., T.H. Maze, and R. Souleyrette. Impacts of weather on urban freeway traffic flow characteristics and facility capacity. in Proceedings of the 2005 midcontinent transportation research symposium. 2005.

14. Akin, D., V.P. Sisiopiku, and A. Skabardonis, Impacts of weather on traffic flow characteristics of urban freeways in Istanbul. Procedia-Social and Behavioral Sciences, 2011. 16: p. 89-99.

15. Koetse, M.J. and P. Rietveld, The impact of climate change and weather on transport: An overview of empirical findings. Transportation Research Part D: Transport and Environment, 2009. 14(3): p. 205-221.

16. Qiu, L. and W. Nixon, Effects of adverse weather on traffic crashes: systematic review and meta-analysis. Transportation Research Record: Journal of the Transportation Research Board, 2008(2055): p. 139-146.

17. Rakha, H. and B. Crowther, Comparison of Greenshields, Pipes, and Van Aerde carfollowing and traffic stream models. Transportation Research Record: Journal of the Transportation Research Board, 2002(1802): p. 248-262.

18. Billot, R., N.-E. El Faouzi, and F. De Vuyst, Multilevel Assessment of the Impact of Rain on Drivers' Behavior: Standardized Methodology and Empirical Analysis. Journal of the Transportation Research Board, 2009(2107): p. 134-142. 